\title{
Chiral Kinase Inhibitors
}

\author{
Jian-kang Jiang, Min Shen, Craig J. Thomas*, and Mathew B. Boxer \\ $\mathrm{NIH}$ Chemical Genomics Center, National Human Genome Research Institute, National Institutes \\ of Health, 9800 Medical Center Drive, Rockville, Maryland 20850, USA.
}

\begin{abstract}
Small molecule kinase inhibitors are important tools for studying cellular signaling pathways, phenotypes and are, occasionally, useful clinical agents. With stereochemistry pervasive throughout the molecules of life it is no surprise that a single stereocenter can bestow a ligand with distinct binding affinities to various protein targets. While the majority of small molecule kinase inhibitors reported to date are achiral, a number of asymmetric compounds show great utility as tools for probing kinase-associated biomolecular events as well as promising therapeutic leads. The mechanism by which chirality is introduced varies but includes screening of chiral libraries, incorporation of chiral centers during optimization efforts and the rational installation of a chiral moiety as guided by structural and modeling efforts. Here we discuss several advanced chiral small molecule kinase inhibitors where stereochemistry plays an important role in terms of potency and selectivity.
\end{abstract}

\section{Introduction}

The beginning of our understanding of molecular chirality is often attributed to the work of Jean-Baptiste Biot who first used the term "optically active" to describe substances that rotated polarized light [1]. Boit's pioneering studies on solutions of sugars that rotated polarized light in a concentration dependent manner instigated early pioneering work on the subject. Highlights include Louis Pasteur's separation and study of tartaric acid crystals which spawned a molecular understanding of enantiomers [2]. Jacobus van't Hoff introduced the chiral carbon in 1874 and Emil Fischer determined the 16 stereoisomers of the aldohexoses in 1894 [3, 4]. Fischer then described the lock and key model of binding that today permeates throughout the study of chemistry and biology [5]. As an appreciation for molecular chirality emerged, the realization that enantiomers can have different biological effects began to take hold at the turn of the $19^{\text {th }}$ century. Landmark studies include the different biochemical oxidation rates for the isomers of tartaric acid, arabinose, and mannose; the different taste between D- and L-asparagine and between D- and Lglutamic acid; and the different biological and behavioral effects for dextro-cocaine and laevo-cocaine, atrsocine and scopolamine, as well as atropine and hyoscyamines [6]. The Easson-Stedman hypothesis marked a key recognition that crucial multi-point interactions between chiral small molecules and their chiral protein targets existed [7]. The successful high-resolution X-ray structure of sperm whale myoglobin gave the first detailed 'snapshot' of a large biomolecule where the effects of chirality on tertiary protein structure were displayed [8].

As synthetic approaches toward library development and advances in biological assay techniques were made, small molecules that perturbed specific biochemical events were

"Corresponding author: craigt@nhgri.nih.gov, Send proofs to: Dr. Craig J. Thomas, NIH Chemical Genomics Center, NHGRI, National Institutes of Health, 9800 Medical Center Drive, Building B, Room 3005, MSC: 3370, Bethesda, MD 20892-3370. 
discovered at an increasing pace. Even with the considerable history of chirality and its role in biology, most biologically active small molecules were synthesized, reported and studied as achiral entities or racemic mixtures (excluding natural products). Expectedly, these racemic and achiral compounds dominated the drug landscape for the better part of the $20^{\text {th }}$ century. However, a recent and significant increase in fully synthetic drugs with defined stereochemical requirements has been documented $[9,10]$. In large part, this is due to advances in large scale chiral separation techniques and asymmetric reactions. Currently, there are a growing number of optically pure chiral auxiliaries, catalysts and starting reagents available from commercial sources. As a result, more studies are emerging that describe the biochemical activity, pharmacokinetics and pharmacodynamics of small molecule stereoisomers. Many of these studies have established that one stereoisomer can have a desired pharmacological effect, while its enantiomer or diastereomer(s) can have a range of effects including: identical activity, lower activity, no activity and even fully opposing activity at the same target. To this end, in 1992 the US FDA stated that "to evaluate the pharmacokinetics of a single enantiomer or mixture of enantiomers, manufacturers should develop quantitative assays for individual enantiomers in in vivo samples early in drug development. This will allow assessment of the potential for interconversion and the absorption, distribution, biotransformation, and excretion (ADBE) profile of the individual isomers" [11]. This statement coincided with a significant increase in the worldwide approval of single enatiomer new molecular entities (NME) $[9,10]$.

The role of chirality has permeated drug discovery efforts within all major target classes of the drugable genome. A major category of the drugable genome remains the kinome and kinase inhibitors represent an important class of small molecule tools and clinically explored agents. The majority of kinase inhibitors discovered to date are ATP-competitive inhibitors known as type I inhibitors. One of the first reported ATP-competitive inhibitors is the natural product staurosporine (Figure 1), known to be a potent pan-kinase active compound $[12,13]$. While the lack of selectivity and high toxicity of this compound prevent it from becoming a useful drug, it has remained a benchmark control compound for a myriad of assays. The role of selectivity when targeting the kinome is an active area of research and debate $[14,15]$. As there are over 500 kinases in the human genome it is important to state that selectivity plays a key role in the discovery of appropriate tool compounds to explore specific biological questions. The discovery and approval of imatinib (Figure 1) for treatment of chronic myelogenous leukemia (CML) validated the notion that selective agents can yield positive clinical results. There are currently over 70 kinase inhibitors in various stages of clinical development and each exhibits a different level of selectivity [16]. A second class of kinase inhibitors recognizes the inactive conformation of kinases and have been dubbed type II inhibitors. This variety of inhibitors, which include imatinib and sorafenib (Figure 1), often bind at locales with more structural divergence relative to the highly homologous ATP-binding sites. As a result, type II inhibitors can often be engineered to have higher selectivity profiles $[17,18]$. Discovery of a type II or fully allosteric kinase inhibitor can be complicated and screening efforts typically yield a higher percentage of type I inhibitors. The incorporation of stereocenters is one strategy to confer selectivity to a type I inhibitor by taking advantage of the subtle three-dimensional differences found within the ATP binding domain. Given the preeminent role that kinases play in signal transduction pathways and the well characterized dysregulation of selected kinases within numerous diseases [14-16, 19-21] it is clear that there exists a need for novel kinase inhibitors. Here, we explore the imaginative ways that researchers have bestowed both potency and selectivity upon novel small molecule kinase inhibitors through the incorporation of chirality. 


\section{Discovery of the p38a inhibitor $\mathrm{PH}-797804$}

The mitogen-activate protein kinases (MAPKs) are serine/threonine protein kinases that regulate numerous cellular responses to varied external stimuli. A prominent member of the MAPK family are the $\mathrm{p} 38$-isoforms $-\alpha,-\beta,-\gamma$, and $-\delta$. The $\mathrm{p} 38 \alpha$ isoform (also known as MAPK14) is encoded by the MAPK14 gene and is known to be widely expressed in various tissue types including leukocytes, epithelial cells and smooth muscle cells [22-26]. p38 $\alpha$ is among the most widely studied MAPK isoforms with over 50 disclosed X-ray structures containing a variety of bound ligands. MAP kinase kinases (MKKs), particularly MKK3 and MKK6, are responsible for the activation of $\mathrm{p} 38 \alpha$ in response to several characterized stimuli including proinflammatory cytokines and various environmental stresses. Activation of $\mathrm{p} 38 \alpha$ has several consequences including increased expression of TNF $\alpha$, IL6, IL1, COX-2 and metalloproteinases $[22,23]$. Given its role as a key mediator of the inflammation process [23], p38 $\alpha$ has emerged as a key target within the study of a variety of diseases including rheumatoid arthritis, Crohn's disease, atherosclerosis, chronic obstructive pulmonary disease (COPD), severe asthma and psoriasis. As a result, numerous p38 inhibitors have been disclosed with a myriad of activities in preclinical disease models including significant mitigation of cytokine release within inflammation models, reduction of cardiac hypertrophy, protection against cardiac remodeling and treatment of COPD [27-36].

A recent addition to the p38 $\alpha$ inhibitor pipeline is $\mathbf{P H - 7 9 7 8 0 4}$, an axially chiral, potent, selective and orally bioavailable p38 $\alpha$ inhibitor (Figure 2)[37]. This relatively unique chiral compound was purified by chiral chromatography to isolate both the $R$ - and $S$-isomers. The ability to resolve the atropisomers arises from the high rotational energy barrier caused by the 6- and 6'-methyl substituents on the phenyl and pyridinone rings. The authors used molecular modeling to determine a barrier of $>25 \mathrm{kcal} / \mathrm{mol}$ for rotation around the $N$-phenyl bond. The $S$-atropisomer (PH-797804) was determined to be a $>100$-fold more potent $\mathrm{p} 38 \alpha$ inhibitor than the $R$-isomer and an X-ray structure of the compound bound to $\mathrm{p} 38 \alpha$ has been reported (PDB:3HLL)(Figure 2). Examination of this crystal structure illustrates that the methyl amide group on the $S$-atropisomer is positioned in an open pocket.(referred to as the $\mathrm{E}_{0}$ region). On the basis of this structure, it is likely that the methyl amide in the $R$ atropisomer encounters unfavorable steric interactions with Asp112 and Asn115. PH-797804 is an ATP-competitive inhibitor and structural comparison of p38 $\gamma$-AMP-PNP and PH-797804-p38 $\alpha$ co-crystals illustrated that the pyridinone of PH-797804 likely overlaps with the adenine moiety of ATP. PH-797804 contains a hydrophobic 2,4difluorophenyl group that extends into a lipophilic pocket of $\mathrm{p} 38 \alpha$ that is controlled by the Thr106 gatekeeper residue. This important hydrophobic interaction, along with two key hydrogen bonds between the pyridinone carbonyl of PH-797804 and Met109 and Gly110 are presumed sources of the potency and selectivity of this kinase inhibitor. Interestingly, the Met109-Gly110 amide bond is inverted relative to its native conformation permitting this critical hydrogen bond. Importantly, the atropoisomerism of PH-797804 helps govern the binding vector of the pyridinone moiety further facilitating this key hydrogen bond. Reasoning that the Thr106 gatekeeper and the Gly110 amide bonds rotation are keys to activity for this chemotype, a bioinformatics analysis was done and revealed that $\mathrm{p} 38 \beta$ and Myt-1 enzymes contain the TXXXG motif in the active site. Importantly, no activity for PH-797804 against Myt-1 was observed and a 10-fold higher $\mathrm{IC}_{50}$ value was seen for $\mathrm{p} 38 \beta$ compared to p38 $\alpha$. PH-797804 was screened again two kinase panels and showed high selectivity against other MAP kinase members as well as the JNK kinases. Importantly, PH-797804 showed $<20 \%$ inhibition (up to $10 \mu \mathrm{M}$ ) against a number of kinases containing either a Thr106 or Gly110 homolog. Cellular assays demonstrated that PH797-804 ablated p38 $\alpha$ signaling while having no appreciable inhibition of JNK and ERK or phosphorylation of c-Jun. Pfizer has now completed phase II trials with PH-797804 for the treatment of 
neuropathic pain associated with post-herpetic neuralgia and phase II clinical trials for the treatment chronic obstructive pulmonary disease are currently ongoing.

\section{Discovery of the AKT inhibitors A-443654 and pyrimidine 3}

The AKT family of kinases (also known as protein kinase B, PKB) are serine/threonine kinases that are important cellular signaling mediators and regulators of a myriad of cellular functions including protein synthesis, cell survival and proliferation, metabolism, neurological activity, and cardiovascular homeostasis [38-52]. AKT is a primary agent within PI3K signaling following phosphorylation by PDK1 and/or the mTORC2 complex [51]. The list of AKT interactions continues to grow and currently contains over 25 known roles including its phosphorylation of GSK3, FOXO transcription factors, MDM2, TSC1/2, and $\mathrm{BAD}$. Because AKT regulates a large number of cellular functions and hyperactivation of AKT has been observed in many cancers, this protein has emerged as an important target for a variety of diseases. AKT's nodal role in a number of tumor-associated processes has spurred research that has shown blockage of AKT signaling results in reduced cell proliferation and induces apoptosis in cells overexpressing AKT.

Given the myriad of functions associated with the AKT family, numerous potent and selective inhibitors of this class of kinases been discovered (including type I and fully allosteric inhibitors)[53-60]. Phosphatidylinositol analogs have been developed that interfere with the binding of the PH domain of AKT with phosphatidylinositol $(3,4,5)$ triphosphate [61-63]. The use of small peptides $(\leq 20$-mer) resembling AKT's endogenous substrates have been examined and several show moderate potency and good selectivity [64, 65]. Attempts have been made to reduce the size of the amino acid sequence with little success. An amino-pyrimido-pyridazine with a chiral pentose-like appendage (API-2/TCN) was found to inhibit AKT2-transformed cells through screening of the NCI Diversity Set [66]. This molecule selectively inhibits phosphorylation of BAD, AFX and GSK-3 $\beta$ and positive results in mouse xenograft model with aberrant AKT signaling have prompted examination in Phase I trials.

In addition to these agents, Abbott Laboratories has disclosed a number of potent, pan-AKT inhibitors that show moderate to high selectivity over PKA [67]. A high-throughput screening (HTS) effort uncovered a chloropyridine $(1$, AKT IC $50=5 \mu \mathrm{M})$ containing a chiral secondary amine. The subsequent optimization effort discovered A-443654 (AKT1 $\mathrm{IC}_{50}=0.16 \mathrm{nM}$ ) that retained the chiral amine functionality and possessed impressive selectivity and cell-based activity (Figure 3). Continued optimization has led to a related inhibitor that retains the chiral amine and possesses improved kinase selectivity, a good safety profile and moderate oral bioavailability. An X-ray structure has been reported of A-443654 bound to PKA, which is commonly used as a surrogate for AKT due to its relative ease of crystallization and homology with AKT at the ATP binding site (PDB:2UZU) (Figure 3). Astex Therapeutics has subsequently released a structure of A-443654 bound to AKT2 (PDB:2JDR) and PKA (PDB:2JDS)(Figure 3)[68]. Interestingly, these structures illustrate moderately divergent binding orientations for A-443654. The methyl-indazole and pyridine adopt a matching binding mode whereby key hydrogen-bonds to the hinge region are found in both crystal structures. In contrast, the indole moiety is significantly divergent in its binding modality within the AKT2 and PKA structures. In PKA, the indole is oriented towards the glycine rich loop (cyan colored structure), while in AKT2 (purple colored structure), the indole ring is directed toward the ATP-binding pocket and a new hydrophobic pocket containing Met282, Phe439 and Val166 residues. The chiral primary amine occupies a similar position in both structures, forming key hydrogen bonds with Asp and Asn residues in an 'acidic pocket.' The chiral nature of the secondary amine imposes directionality on the indole moiety resulting in key hydrophobic interactions and hydrogen bonds. It can be 
argued that the 40-fold selectivity for AKT over PKA arises from the orientation imposed by the chiral nature of the molecule as it dictates specific interactions with the divergent amino acid residues found in each binding pocket.

In 2006, Chiron Corporation published a potent AKT inhibitor that incorporated a chiral (2aminoethyl)amide moiety (Figure 4)[69]. This agent derived from an achiral 2-aminopyrimidine screening lead possessed a $3.0 \mu \mathrm{M} \mathrm{IC}_{50}$ value versus AKT. The lead structure evolved into a 2-pyrimidyl-5-amidothiophene core in which a variety of chirally pure analogues were evaluated including tertiary amines, terminal alcohols, esters, alkyl groups, and extended alkyl linkers. This effort revealed a preference for a 2-aminoethyl substituent with the $S$-configuration at the homobenzyl position (pyrimidine 3 ). The $R$ enantiomer was found to be $\sim 100$-fold less potent. An X-ray structure of $\mathbf{3}$ bound to PKA has been reported (PDB:2GU8)(Figure 4). Key hydrogen bonds between the primary amine and Asn171 and Asp184 make evident the importance of the $S$-configuration. A water-mediated hydrogen bond with Asp166 denotes a secondary binding construct that is enabled by the exact placement of the primary amine. The $S$-configuration also orients the dichlorophenyl group into a hydrophobic pocket created by the glycine rich loop. This example highlights the transformation of an achiral screening lead into a novel, chiral agent and underscores the importance of examining chirality during SAR explorations.

\section{Discovery of the ERK inhibitors FR148083 and pyrimidine 7}

The RAS/RAF/MEK/ERK signal transduction pathway is a well-studied and important cascade with relevance to numerous disease states with particular significance within many types of cancers [70-73]. The first FDA approved drug targeting this pathway is Sorafenib (Nexavar) [74], an inhibitor of multiple receptor protein kinases including RAFs $\left(\mathrm{IC}_{50}\right.$ values for B-RAF and C-RAF are 6 and $22 \mathrm{nM}$, respectively), which is indicated for the treatment of renal cell carcinoma. Several MEK inhibitors have been advanced to clinical trials including PD0325901, AZD142886/ARRAY6244 and RDEA119 [75,76]. ERK lies downstream in the RAS/RAF/MEK cascade and is an important node for several signaling pathways. A primary phenotype affected by ERK is the activation of cell proliferation, survival and growth making ERK inhibitors highly sought after entities. Inhibitors of ERK activity are envisioned as potential therapeutics within cancer as well as other RAS/RAF/ MEK/ERK pathway related diseases.

Numerous efforts aimed at discovering ERK inhibitors have been reported including the discovery of the natural product FR148083 (also known as LL-Z-1640-2). FR148083 is reported to be an ATP competitive inhibitor of several kinases including MEK and ERK2 $\left(\mathrm{IC}_{50}\right.$ values of $4 \mathrm{nM}$ and $80 \mathrm{nM}$, respectively)(Figure 5) [77-81]. There are several key structural features of FR148083 including three chiral centers, a trans alkene and a cis $\alpha, \beta$ unsaturated ketone functionality. Ohori et al reported a crystal structure of ERK2 bound to FR148083 which revealed a covalent bond between Cys166 and the $\alpha, \beta$-unsaturated ketone functionality (PDB:2E14)(Figure 5)[77]. This structure further revealed that the two chiral hydroxyl groups form hydrogen bonds with Ser153 and Asn154 of ERK2 and the C10' methyl group is within the van der Waals range of a number of hydrophobic residues. This structure demonstrates that the stereochemistry of each chiral center and both double bonds imparts a unique three-dimensionality that plays a crucial role in the binding of FR148083 to ERK2. Numerous structure activity studies on FR148083 and the related natural product hypothemycin provide experimental data that confirms the roles of each of these stereocenters.

Researchers at Vertex Pharmaceuticals recently disclosed a small molecule ATPcompetitive ERK2 inhibitor that relies heavily on a key chiral (2-hydroxyethyl)amide 
moiety for its potent and selective binding. This agent was derived from a screening lead bearing a pyrazolylpyrrole scaffold $\left(4, K_{\mathrm{i}}=2.3 \mu \mathrm{M}\right)$ (Figure 6)[82,83]. A crystal structure of 4 bound to ERK2 indicated the pyrazolylpyrrole core maintained several pivotal hydrogen bonds to key residues within the kinase hinge region. Advancement of this lead included SAR explorations of the phenyl ring and dimethyl-amide moiety ultimately yielding $\mathbf{5}\left(K_{\mathrm{i}}=\right.$ $86 \mathrm{nM})$. An undesired interaction of 5 with JNK3 $\left(K_{\mathrm{i}}=550 \mathrm{nM}\right)$ prompted further evaluation. Crystal structures of 5 bound to ERK2 and JNK3 demonstrated an inversion of the binding alignment at JNK3 as compared to ERK2. The addition of a hydrogen bond donor at the benzylic methylene position was posited as means to engage hydrogen bond accepting residues within ERK2 while encountering adverse steric interactions within JNK3. The introduction of a chiral methyl group at the benzyl position gave a $\sim 2$-fold shift in potency. Incorporating a chiral hydroxymethyl ( $S$-configuration) on the benzyl carbon and adjustment to a 3-chloro-4-fluoro substitution pattern yielded an analogue (6) with a $>40$ fold shift in potency $\left(K_{\mathrm{i}}=2 \mathrm{nM}\right.$ for ERK2) and selectivity of JNK3 (>2000-fold). The corresponding analogue with the $R$-configuration was 75 times less potent. The crystal structure of ERK2 bound to 6 confirmed that the $(S)$-phenylglycinol engaged two key hydrogen bonds with the carboxylate of Asp165 and the carboxamide of Asn152 (PDB: 2OJJ)(Figure 6). A newer generation of these agents were recently reported that continue the use of the (S)-phenylglycinol amide motif [83]. An advanced derivative (7) possessed $<2$ nM ERK2 inhibition with >200-fold selectivity over GSK3, CDK2 and AuroraA and >500fold selectivity over a large kinase panel. In HT29 cell proliferation assay 7 had an $\mathrm{IC}_{50}=48$ $\mathrm{nM}$ and showed good oral bioavailability in both rat and mouse models.

\section{Discovery of the JAK3 inhibitor CP-690,550}

JAK3 is a non-receptor tyrosine kinase belonging to the JAK family that includes four homologous kinases: JAK1, JAK2, JAK3 and TYK2. JAK3 is a primary signaling component for cytokine receptors that respond to interleukin (IL)-2, IL-4, IL-7, IL-9, IL-15 and IL-21) [84]. JAK3 is phosphorylated in response to cytokine binding ultimately resulting in Stat phosphorylation and activation [85]. Because of JAK3's role in $\gamma c$ cytokine signaling regulation, a selective JAK3 inhibitor could potentially be useful as an agent for the treatment of autoimmune-related disorders and there are numerous reports of JAK3 inhibitors. In 2003, researchers from Pfizer reported CP-690,550, a potent and selective JAK3 inhibitor (Figure 7)[86]. While no relative or absolute configuration was given for the two chiral carbons, the report gave $\mathrm{IC}_{50}$ values of 1,20 and $112 \mathrm{nM}$ for JAK3, JAK2 and JAK1 respectively. The absolute configuration was disclosed as $3 R, 4 R$ for the piperidin-1yl-3-oxopropanenitrile based drug in subsequent reports [87-91]. Jiang and coworkers developed a strategy allowing the synthesis of all four stereoisomers of CP-690,550 by employing L- or D-serine as the starting material [92]. Cell-based assays utilizing all four stereoisomers uncovered that only $\mathbf{C P - 6 9 0 , 5 5 0}$ was capable of disrupting JAK3 mediated Stat5 phosphorylation at the tested concentrations. This result highly suggests that alternative stereochemical configurations are deleterious to the inhibition activity at JAK3. A profile of a panel of 354 kinases was performed for all four stereoisomers and found that CP-690,550 possessed similar binding affinities for JAK3, JAK2 and JAK1 ( $K$ d values of $0.7,2$ and $3 \mathrm{nM}$, respectively). This contrasted the original report which detailed a modest degree of selectivity for JAK3 over JAK2 and JAK1. Notably, a significant potency drop for JAK2 and JAK3 was documented for stereoisomers 8, 9, and $10\left(K_{\mathrm{d}}\right.$ values; 10: JAK2 $=600$ nM, JAK3= 190 nM; 11: JAK2=270 nM, JAK3= 180 nM; 12: JAK2= 420 nM, JAK3= 150 $\mathrm{nM}$ (Figure 7). A recent patent detailed additional SAR for this agent distinctly detailing the importance of the chiral methyl group on $\mathrm{C} 4$ of piperidine ring. A series of sulfonamide analogues demonstrated that removal of the $\mathrm{C} 4$ methyl group caused a significant decrease in potency for JAK3 [93]. In 2009, Lucet and coworkers reported the crystal structures of JAK1 and JAK2 bound to CP-690,550 (PDB:3EYG)(Figure 7)[94]. Based on the homology 
of JAK1, JAK2 and JAK3 it is likely that CP-690,550 adopts a similar binding pose at JAK3. Several structural features highlighted the role that chirality plays in the binding of CP-690,550 to JAK1/JAK2. Similar to other purine-like inhibitors, the pyrrolepyrimidine ring forms two hydrogen bonds with Glu957 and Leu959 at the hinge region of JAK1. The $3 R, 4 R$ stereochemistry of piperidine ring orients the cyanoacetyl group toward a pocket formed by the glycine-rich loop. The remainder of the CP-690,550 structure appears to engender binding affinity through space filling/van der Waals interactions and the chiral nature of this compound significantly governs this key aspect of CP-690,550 binding.

\section{Discovery of the TrkA inhibitors isothiazole 14 and AZ-23}

The tropomyosin-receptor kinases (Trk) and their ligands are discreetly involved with neuronal cell growth and survival. Neurotrophins (growth factors) are typical ligands of the Trk receptors and are important proteins involved in the survival, development and function of neurons. TrkA, the first discovered tropomyosin-receptor kinase, mediates nerve growth factor (NGF) effects such as neuronal differentiation and survival [95-97]. Upon NGF binding, autophosphorylation of Trk increases the catalytic activity of the kinase domain and initiates the downstream signal transduction pathway [98]. Specifically, the Trk receptors have been discovered to have roles in malignant transformation, metastasis and survival signaling in tumors [99-101]. Over-expression of Trk and NGF has been found in many types of human cancers, particularly prostate and pancreatic cancers $[102,103]$. Development of TrkA inhibitors has drawn much attention as potential cancer treatments along with other therapeutic implications.

Researchers from Pfizer reported a series of isothiazole derivatives as potent TrkA inhibitors in 2006 [104]. A high-throughput screening effort uncovered the substituted isothiazole 11 as a lead with an $\mathrm{IC}_{50}$ values of $7 \mathrm{nM}$ and $300 \mathrm{nM}$ against TrkA kinase and TrkA cell-based studies, respectively (Figure 8). Examination of this agents selectivity revealed that this compound possessed only modest selectivity over VEGFR2. A homology model of TrkA revealed a lipophilic pocket that was exploited to garner selectivity over VEGFR2. Introduction of a variety of substituents at the benzylic position uncovered the $R$-ethyl substituted 12 that possessed a 1300-fold selectivity for TrkA over VEGFR2. The corresponding $S$-isomer (13) had moderately good potency but only a 10 -fold selectivity for TrkA over VEGFR2. Further SAR examinations led to the discovery of a highly potent and selective compound (14) that had sub-nanomolar potency in the biochemical assay and a 7 $\mathrm{nM} \mathrm{IC}_{50}$ value in the cell based study. The importance of this chiral center was showcased by the fact that the $S$-isomer (15) was significantly less active versus TrykA and within the cell-based assay.

Reports in 2008 and 2009 from AstraZeneca detailed a series of pyrimidine-2,4-diamines as potent TrkA inhibitors [105,106]. The bromopyrimidine-2,4-diamine $\mathbf{1 6}$ was discovered from an HTS effort to possess an $\mathrm{IC}_{50}$ of $270 \mathrm{nM}$ against TrkA and $1.1 \mu \mathrm{M}$ against TrkB (Figure 9). During optimization several key structural changes were made including alteration from 3-methylisoxazole to phenyl and alteration of the benzyl position. The benzyl position was presumed to be prone to metabolic oxidation. To address this issue the authors examined several moieties at this position including methyl group which were examined as pure enantiomers $\mathbf{1 7}$ and $\mathbf{1 8}$. The $S$-isomer (18) was found to possess a significantly lower IC50 value than the R-isomer in a cell-based assay of TrkA. However, this analogue suffered from poor solubility and selected PK properties. Continued modifications resolved these issues resulting in the discovery of $\mathbf{A Z - 2 3}$, which possess an $\mathrm{EC}_{50}$ of approximately $2 \mathrm{nM}$ for TrkA in a cell based analysis. AZ-23 was reported to possess good aqueous solubility $(100 \mu \mathrm{M})$, oral bioavailability and appropriate PK properties warranting advanced studies. AZ-23 also has a promising selectivity profile 
versus a large panel of kinases including FGFR1, Flt3, Ret, MuSK, Lck, EphA2, FGFR3, IR, and JAK2 [103]. This ATP-competitive inhibitor blocked tumor growth in an engineered TrkA-driven allograft model as well as a xenograft model.

\section{Conclusions and Perspectives}

Chirality is playing an ever-increasing role in pharmacology and drug discovery and chiral small molecules are rapidly establishing themselves as attractive probe compounds and clinical reagents. The kinome is a major segment of the drugable genome and kinase inhibitors are an established division of the pharmacopeia and chiral kinase inhibitors are beginning to appear at an increased pace. A single chiral center can instill otherwise unachievable subtlety toward the binding interactions of a ligand at highly homologous domains of kinases bestowing selectivity and potency that often eludes achiral small molecules. Here, we have highlighted several examples whereby chirality has altered the potency, selectivity, cell-based efficacy and even DMPK properties of a kinase inhibitor. Given these successes and continued advances in asymmetric synthetic and separation technologies it is likely that stereochemistry will no longer be avoided during efforts to discover and optimize novel ligands targeting the kinome and beyond.

\section{Acknowledgments}

The authors would foremost like to acknowledge the talent, work and ingenuity of the researchers whose work is reviewed in this manuscript. We thank Ms. Allison Mandich for critical reading of this manuscript. Research at the NIH Chemical Genomics Center is supported by the Molecular Libraries Initiative of the National Institutes of Health Roadmap for Medical Research and the Intramural Research Program of the National Human Genome Research Institute, National Institutes of Health.

\section{References}

1. Biot JB. Me'moire sur les rotations que certaines substances impriment aux axes de polarisation des rayons lumineux.'. Memoires de l'Academie des Sciences. 1818; Vol. II:41-136.

2. Dubos, R. Louis Pasteur: Free Lance of Science. Boston, MA: Little, Brown and Co.; 1950.

3. Meijer EW. Jacobus Henricus van 't Hoff; Hundred years of impact on stereochemistry in the Netherlands. Angew. Chem. Int. Ed. 2001; 40:3783-3789.

4. See following reference and references therein: Emil Fischer, Kunz H. Unequalled classicist, master of organic chemistry research, and inspired trailblazer of biological chemistry. Angew. Chem. Int. Ed. 2002; 41:4439-4451.

5. Fischer E. Einfluss der configuration auf die wirkung der enzyme. Ber. Dt. Chem. Ges. 1894; 27:2985-2993.

6. Cushny AR. Atropine and the hyoscyamines-a study of the action of optical isomers. J. Physiol. 1903; 30:176-194. and references therein. [PubMed: 16992694]

7. Easson LH, Stedman E. CLXX. Studies on the relationship between chemical constitution and physiological action. Biochem. J. 1933; 27:1257-1266. [PubMed: 16745220]

8. Kendrew JC, Bodo G, Dintzis HM, Parrish RG, Wyckoff H, Phillips DC. A three-dimensional model of the myoglobin molecule obtained by X-ray analysis. Nature. 1958; 181:662-666. [PubMed: 13517261]

9. Caner H, Groner E, Levy L. Trends in the development of chiral drugs. Drug Discovery Today. 2004; 9:105-110. [PubMed: 15038394]

10. American Medical Association website: http://www.ama-assn.org, under Geometric isomerism and chirality: the USAN perspective.

11. FDA website: http://www.fda.gov, under Development of New Stereoisomeric Drugs. published $5 / 1 / 1992$. 
12. Tamaoki T, Nomoto H, Takahashi I, Kato Y, Morimoto M, Tomita F. Staurosporine, a potent inhibitor of phospholipid/Ca ${ }^{++}$dependent protein kinase. Biophys. Res. Commun. 1986; 135:391402.

13. Rüegg UT, Burgess GM. Staurosporine, K-252 and UCN-01: potent but nonspecific inhibitors of protein kinases. Trends Pharmacol. Sci. 1989; 10:218-220. [PubMed: 2672462]

14. Knight ZA, Shokat KM. Features of selective kinase inhibitors. Chem. Biol. 2005; 12:621-637. [PubMed: 15975507]

15. Liao JJ-L. Molecular targeting of protein kinases to optimize selectivity and resistance profiles of kinase inhibitors. Curr. Top. Med. Chem. 2007; 7:1332-1335. [PubMed: 17692023]

16. Gill AL, Verdonk M, Boyle RG, Taylor R. A comparison of physicochemical property profiles of marketed oral drugs and orally bioavailable anticancer protein kinase inhibitors in clinical development. Curr. Top. Med. Chem. 2007; 7:1408-1422. [PubMed: 17692029]

17. Levitzki A, Mishani E. Tyrphostins and other tyrosine kinase inhibitors. Annu. Rev. Biochem. 2006; 75:93-109. [PubMed: 16756486]

18. Liao JJ-L, Andrews RC. Targeting protein multiple conformations: A structure-based strategy for kinase drug design. Curr. Top. Med. Chem. 2007; 7:1394-1407. [PubMed: 17692028]

19. Noble MEM, Endicott JA, Johnson LN. Protein kinase inhibitors: insights into drug design from structure. Science. 2004; 303:1800-1805. [PubMed: 15031492]

20. Goldstein DM, Gray NS, Zarrinkar PP. High-throughput kinase profiling as a platform for drug discovery. Nature Rev. Drug Discov. 2008; 7:391-397. [PubMed: 18404149]

21. Jänne PA, Gray N, Settleman JF. Factors underlying sensitivity of cancers to small-molecule kinase inhibitors. Nature Rev. Drug Discov. 2009; 8:709-723. [PubMed: 19629074]

22. Schieven GL. The biology of p38 kinase: A central role in inflammation. Curr. Top. Med. Chem. 2005; 5:921-928. [PubMed: 16178737]

23. Schieven GL. The p38 $\alpha$ kinase plays a central role in inflammation. Curr. Top. Med. Chem. 2009; 9:1038-1048. [PubMed: 19747121]

24. Mayer RJ, Callahan JF. p38 MAP kinase inhibitors: A future therapy for inflammatory diseases. Drug. Discov. Today: Therap. Strategies. 2006; 3:49-54.

25. Brancho D, Tanaka N, Jaeschke A, Ventura J-J, Kelkar N, Tanaka Y, Kyuuma M, Takeshita T, Flavell RA, Davis RJ. Mechanism of p38 MAP kinase activation in vivo. Genes Dev. 2003; 17:1969-1978. [PubMed: 12893778]

26. Lee JC, Laydon JT, McDonnell PC, Gallagher TF, Kumar S, Green D, McNulty D, Blumenthal MJ, Heys JR, Landvatter SW, Strickler JE, McLaughlin MM, Siemens IR, Fisher SM, Livi GP, White JR, Adams JL, Young PR. A protein kinase involved in the regulation of inflammatory cytokine biosynthesis. Nature. 1994; 372:739-746. [PubMed: 7997261]

27. Schett G, Zwerina J, Firestein G. The p38 mitogen-activated protein kinase (MAPK) pathway in rheumatoid arthritis. Ann. Rheum. Dis. 2008; 67:909-916. [PubMed: 17827184]

28. Behr TM, Berova M, Doe CP, Ju H, Angermann CE, Boehm J, Willette RN. p38 Mitogenactivated protein kinase inhibitors for the treatment of chronic cardiovascular disease. Curr. Opin. Invest. Drugs. 2003; 4:1059-1064.

29. Dominguez C, Powers DA, Tamayo N. p38 MAP kinase inhibitors: Many are made, but few are chosen. Current. Opin. Drug Discov. Dev. 2005; 8:421-430.

30. Pettus LH, Wurz RP. Small molecule p38 kinase inhibitors for the treatment of inflammatory diseases: novel structures and developments during 2006-2008. Curr. Top. Med. Chem. 2008; 8:1452-1467. [PubMed: 18991731]

31. Karcher SC, Laufer SA. Successful structure-based design of recent p38 MAP kinase inhibitors. Curr. Top. Med. Chem. 2009; 9:655-676. [PubMed: 19689372]

32. Jackson PF, Bullington JL. Pyridinylimidazole based p38 MAP kinase inhibitors. Curr. Top. Med. Chem. 2002; 2:1011-1020. [PubMed: 12171568]

33. Goldstein DM, Gabriel T. Pathway to the clinic: inhibition of P38 MAP kinase. A review of ten chemotypes selected for development. Curr. Top. Med. Chem. 2005; 5:1017-1029. [PubMed: 16178744]

Curr Top Med Chem. Author manuscript; available in PMC 2011 November 18. 
34. Cirillo PF, Pargellis C, Regan J. The non-diaryl heterocycle classes of p38 MAP kinase inhibitors. Curr. Top. Med. Chem. 2002; 2:1021-1035. [PubMed: 12171569]

35. Natarajan SR, Doherty JB. P38 MAP kinase inhibitors: Evolution of imidazole-based and pyridopyrimidin-2-one lead classes. Curr. Top. Med. Chem. 2005; 5:987-1003. [PubMed: 16178742]

36. Peifer C, Wagner G, Laufer S. New approaches to the treatment of inflammatory disorders small molecule inhibitors of p38 MAP kinase. Curr. Top. Med. Chem. 2006; 6:113-149. [PubMed: 16454763]

37. Xing L, Shieh HS, Selness SR, Devraj RV, Walker JK, Devada B, Hope HR, Compton RP, Schindler JF, Hirsch JL, Benson AG, Kurumbail RG, Stegeman RA, Williams JM, Broadus RM, Walden Z, Monahan JB. Structural bioinformatic-based prediction of exceptional selectivity of p38 MAP kinase inhibitor PH-797804. Biochemistry. 2009; 48:6402-6411. [PubMed: 19496616]

38. Cho H, Mu J, Kim JK, Thorvaldsen JL, Chu QW, Crenshaw EB, Kaestner KH, Bartolomei MS, Shulman GI, Birnbaum MJ. Insulin resistance and a diabetes mellitus-like syndrome in mice lacking the protein kinase Akt2 (PKB $\beta$ ). Science. 2001; 292:1728-1731. [PubMed: 11387480]

39. Lu Y, Wang H, Mills GB. Targeting PI3K-AKT pathway for cancer therapy. Rev. Clin. Exp. Hematol. 2003; 7:205-228. [PubMed: 14763163]

40. Luo J, Manning BD, Cantley LC. Targeting the PI3K-Akt pathway in human cancer: rationale and promise. Cancer Cell. 2003; 4:257-262. [PubMed: 14585353]

41. Garofalo RS, Orena SJ, Rafidi K, Torchia AJ, Stock JL, Hildebrandt AL, Coskran T, Black SC, Brees DJ, Wicks JR, McNeish JD, Coleman KG. Severe diabetes, agedependent loss of adipose tissue, and mild growth deficiency in mice lacking Akt2/PKBß. J. Clin. Invest. 2003; 112:197208. [PubMed: 12843127]

42. Mitsiades CS, Mitsiades N, Koutsilieris M, Nicholson KM, Anderson NG, Neri LM, Borgatti P, Capitani S, Martelli M, Brazil DP, Hemmings BA. The Akt pathway: molecular targets for anticancer drug development. Curr. Cancer Drug Targets. 2004; 4:235-256. [PubMed: 15134532]

43. Altomare DA, Testa JR. Perturbations of the AKT signaling pathway in human cancer. Oncogene. 2005; 24:7455-7464. [PubMed: 16288292]

44. Chen YL, Law P-Y, Loh HH. Inhibition of PI3K/Akt signaling: an emerging paradigm for targeted cancer therapy. Curr. Med. Chem. Anticancer Agents. 2005; 5:575-589. [PubMed: 16305480]

45. Farese RV, Sajan MP, Standaert ML. Insulin-sensitive protein kinases (atypical protein kinase C and protein kinase B/Akt): actions and defects in obesity and type II diabetes. Exp. Biol. Med. 2005; 230:593-605.

46. Zdychova J, Komers R. Emerging role of Akt kinase/protein kinase B signaling in pathophysiology of diabetes and its complications. Physiol. Res. 2005; 54:1-16. [PubMed: 15717836]

47. Kumar C, Madison V. AKT crystal structure and AKT-specific inhibitors. Oncogene. 2005; 24:7493-7501. [PubMed: 16288296]

48. Cheng JQ, Lindsley CW, Cheng GZ, Yang H, Nicosia SV. The Akt/PKB pathway: molecular target for cancer drug discovery. Oncogene. 2005; 24:7482-7492. [PubMed: 16288295]

49. Testa JR, Tsichlis PN. AKT signaling in normal and malignant cells. Oncogene. 2005; 24:73917393. [PubMed: 16288285]

50. Yoeli-Lerner M, Toker A. Akt/PKB signaling in cancer: a function in cell motility and invasion. Cell Cycle. 2006; 5:603-605. [PubMed: 16582622]

51. Yap TA, Garrett MD, Walton MI, Raynaud F, de Bono JS, Workman P. Targeting the PI3K-AKTmTOR pathway: progress, pitfalls, and promises. Curr. Opin. Pharmacol. 2008; 8:393-412. [PubMed: 18721898]

52. Okuzumi T, Fiedler D, Zhang C, Gray DC, Aizenstein B, Hoffman R, Shokat KM. Inhibitor hijacking of Akt activation. Nat. Chem. Biol. 2009; 5:484-493. [PubMed: 19465931]

53. Lindsley CW, Barnett SF, Yaroschak M, Bilodeau MT, Layton ME. Recent progress in the development of ATP-competitive and allosteric Akt kinase inhibitors. Curr. Top. Med. Chem. 2007; 7:1349-1363. [PubMed: 17692025]

54. Li Q, Zhu GD. Targeting serine/threonine protein kinase B/Akt and cell-cycle checkpoint kinases for treating cancer. Curr. Top. Med. Chem. 2002; 2:939-971. [PubMed: 12171565]

55. Lindsley CW, Zhao Z, Duggan ME, Barnett SF, Defeo- Jones D, Huber HE, Huff JR, Hartman GD, Leister W, Kral A, Fu S, Hancock PJ, Haskell KA, Jones RE, Robinson R. Allosteric Akt

Curr Top Med Chem. Author manuscript; available in PMC 2011 November 18. 
(PKB) kinase inhibitors. Discovery SAR of isozyme selective inhibitors. Bioorg. Med. Chem. Lett. 2005; 15:761-764. [PubMed: 15664853]

56. Barnett SF, Bilodeau MT, Lindsley CW. The Akt/PKB family of protein kinases: A review of small molecule inhibitors and progress towards target validation. Curr. Top. Med. Chem. 2005; 5:109-125. [PubMed: 15853641]

57. Defeo-Jones D, Barnett SF, Fu S, Hancock PJ, Haskell KM, Leander KR, McAvoy E, Robinson RG, Duggan ME, Lindsley CW, Zhao Z, Huber HE, Jones RE. Tumor cell sensitization to apoptotic stimuli by selective inhibition of specific Akt/PKB family members. Mol. Cancer Ther. 2005; 4:271-279. [PubMed: 15713898]

58. Zhao Z, Duggan ME, Barnett SF, Defeo-Jones D, Huber HE, Huff JR, Hartman GD, Leister W, Kral A, Fu S, Hancock PJ, Haskell KA, Jones RE, Robinson R, Lindsley CW. Discovery of 2,3,5trisubstituted pyridine derivatives as potent Akt1 and Akt2 dual inhibitors. Bioorg. Med. Chem. Lett. 2005; 15:905-909. [PubMed: 15686884]

59. Lindsley CW, Bogusky MJ, Leister WH, McClain RT, Robinson R, Barnett SF, Defeo-Jones D, Ross CW III, Hartman GD. Synthesis and biological evaluation of unnatural canthine alkaloids. Tetrahedron Lett. 2005; 46:2779-2782.

60. Bilodeau MT, Balitza AE, Hoffman JM, Manley PJ, Barnett SF, Defeo-Jones D, Haskell K, Jones RE, Leander K, Robinson RG, et al. Allosteric inhibitors of Akt1 and Akt2: a naphthyridinone with efficacy in an A2780 tumor xenograft model. Bioorg. Med. Chem. Lett. 2008; 18:3178-3182. [PubMed: 18479914]

61. Kozikowski AP, Kiddle JJ, Frew T, Berggren M, Powis G. Synthesis and biology of 1D-3deoxyphosphatidylinositol: a putative antimetabolite of phosphatidylinositol-3-phosphate and an inhibitor of cancer cell colony formation. J. Med. Chem. 1995; 38:1053-1056. [PubMed: 7707307]

62. Qiao L, Nan F, Kunkel M, Gallegos A, Powis G, Kozikowski AP. 3-Deoxy-D-myo-inositol 1phosphate, 1-phosphonate, and ether lipid analogues as inhibitors of phosphatidylinositol- 3-kinase signaling and cancer cell growth. J. Med. Chem. 1998; 41:3303-3306. [PubMed: 9719581]

63. Castillo SS, Brognard J, Petukhov PA, Zhang CY, Tsurutani J, Granville CA, Li M, Jung M, West KA, Gills JG, Kozikowski AP, Dennis PA. Preferential inhibition of Akt and killing of Aktdependent cancer cells by rationally designed phosphatidylinositol ether lipid analogues. Cancer Res. 2004; 64:2782-2792. [PubMed: 15087394]

64. Luo Y, Smith RA, Guan R, Liu XS, Klinghofer V, Shen JW, Hutchins C, Richardson P, Holzman T, Rosenberg SH, Giranda VL. Pseudosubstrate peptides inhibit Akt and induce cell growth inhibition. Biochemistry. 2004; 43:1254-1263. [PubMed: 14756561]

65. Livnah, NL.; Yechezkel, T.; Salitra, Y.; Perlmutter, B.; Ohne, O.; Cohen, I.; Litman, P.; Senderowitz, H. WO010281. 2003.

66. Yang L, Dan HC, Sun M, Liu Q, Sun X-m, Feldman RI, Hamilton AD, Polokoff M, Nicosia SV, Herlyn M, Sebti SM, Cheng JQ. Akt/Protein kinase B signaling inhibitor-2, a selective small molecule inhibitor of Akt signaling with antitumor activity in cancer cells overexpressing Akt. Cancer Res. 2004; 64:4394-4399. [PubMed: 15231645]

67. Zhu G-D, Gandhi VB, Gong J, Thomas S, Woods KW, Song X, Li T, Diebold RB, Luo Y, Liu X, Guan R, Klinghofer V, Johnson EF, Bouska J, Olson A, Marsh KC, Stoll VS, Mamo M, Polakowski J, Campbell TJ, Martin RL, Gintant GA, Penning TD, Li Q, Rosenberg SH, Giranda VL. Syntheses of potent, selective, and orally bioavailable indazole-pyridine series of protein kinase B/Akt inhibitors with reduced hypotension. J. Med. Chem. 2007; 50:2990-3003. [PubMed: 17523610]

68. Davies TG, Verdonk ML, Graham B, Saalau-Bethell S, Hamlett CCF, McHardy T, Collins I, Garrett MD, Workman P, Woodhead SJ, Jhoti H, Barford D. A structural comparison of inhibitor binding to PKB, PKA and PKA-PKB chimera. J. Mol. Biol. 2007; 367:882-894. [PubMed: 17275837]

69. Lin X, Murray JM, Rico AG, Wang MX, Chu DT, Zhou Y, Del Rosario M, Kaufman S, Ma S, Fang E, Crawford K, Jefferson AB. Discovery of 2-pyrimidyl-5-amidothiophenes as potent inhibitors for AKT: Synthesis and SAR studies. Bioorg. Med. Chem. Lett. 2006; 16:4163-4168. [PubMed: 16765046] 
70. Sebolt-Leopold JS, Herrera R. Targeting the mitogen-activated protein kinase cascade to treat cancer. Nat. Rev. Cancer. 2004; 4:937-947. [PubMed: 15573115]

71. Smalley KS. A pivotal role for ERK in the oncogenic behaviour of malignant melanoma. Int. J. Cancer. 2003; 104:527-532. [PubMed: 12594806]

72. Kohno M, Pouyssegur J. Pharmacological inhibitors of the ERK signaling pathway: Application as anticancer drugs. Prog. Cell Cycle Res. 2003; 5:219-224. [PubMed: 14593716]

73. Chang F, Steelman LS, Shelton JG, Lee JT, Navolanic PM, Blalock WL, Franklin R, McCubrey JA. Regulation of cell cycle progression and apoptosis by the Ras/Raf/MEK/ERK pathway. Int. J. Oncol. 2003; 22:469-480. [PubMed: 12579299]

74. Investigational drugs database. Thomson Scientific, Ltd.; 2006.

75. Wang J, Wilcoxen KM, Nomoto K, Wu S. Recent advances of MEK inhibitors and their clinical trial progress. Curr. Top. Med. Chem. 2007; 7:1364-1378. [PubMed: 17692026]

76. Iverson C, Larson G, Lai C, Yeh LT, Dadson C, Weingarten P, Appleby T, Vo T, Maderna A, Vernier JM, Hamatake R, Miner JN, Quart B. RDEA119/BAY 869766: A potent, selective allosteric modulator of MEK1/2 for the treatment of cancer. Can. Res. 2009; 69:6839-6847.

77. Winssinger N, Barluenga S. Chemistry and biology of resorcylic acid lactones. Chem. Commun. 2007:22-36.

78. Ohori M, Kinoshita T, Yoshimura S, Varizaya M, Nakajima H, Miyake H. Role of a cysteine residue in the active site of ERK and the MAPKK family. Biochem. Biophys. Res. Comm. 2007; 353:633-637. [PubMed: 17194451]

79. Zhao A, Lee SH, Mojena M, Jenkins RG, Patrick DR, Huber HE, Goetz MA, Hensens OD, Zink DL, Vilella D, Dombrowski AW, Lingham RB, Huang L. Resorcylic acid lactones: naturally occurring potent and selective inhibitors of MEK. J. Antibiot. 1999; 52:1086-1094. [PubMed: 10695671]

80. Ninomiya-Tsuji J, Kajino T, Ono K, Ohtomo T, Matsumoto M, Shiina M, Mihara M, Tsuchiya M, Matsumoto K. A resorcylic acid lactone, 5Z-7-oxozeaenol, prevents inflammation by inhibiting the catalytic activity of TAK1 MAPK kinase kinase. J. Biol. Chem. 2003; 278:18485-18490. [PubMed: 12624112]

81. Jensen BM, Beaven MA, Iwaki S, Metcalfe DD, Gilfillan AM. Concurrent inhibition of kit- and FceRI-mediated signaling: coordinated suppression of mast cell activation. J. Pharmacol. Exp. Ther. 2008; 324:128-138. [PubMed: 17925481]

82. Aronov AM, Baker C, Bemis GW, Cao J, Chen G, Ford PJ, Germann UA, Green J, Hale MR, Jacobs M, Janetka JW, Maltais F, Martinez-Botella G, Namchuk MN, Straub J, Tang Q, Xie X. Flipped out: Structure-guided design of selective pyrazolylpyrrole ERK inhibitors. J. Med. Chem. 2007; 50:1280-1287. [PubMed: 17300186]

83. Aronov AM, Tang Q, Martinez-Botella G, Bemis GW, Cao J, Chen G, Ewing NP, Ford PJ, Germann UA, Green J, Hale MR, Jacobs M, Janetka JW, Maltais F, Markland W, Namchuk MN, Nanthakumar S, Poondru S, Straub J, ter Haar E, Xie X. Structure-guided design of potent and selective pyrimidylpyrrole inhibitors of extracellular signal-regulated kinase (ERK) using conformational control. J. Med. Chem. 2009; 52:6362-6368. [PubMed: 19827834]

84. Pesu M, Laurence N, Kishore N, Zwillich SH, Chan G, O'Shea JJ. Therapeutic targeting of Janus kinases. Immunol. Rev. 2008; 223:132-142. [PubMed: 18613833]

85. Bhandari, R.; Kuriyan, J. Jak-Stat signaling. In: Bradshaw, R.; Dennis, E., editors. Handbook of Cell Signaling. 1st Ed.. New York: Academic Press; 2003. p. 343-347.

86. Changelian PS, Flanagan ME, Ball DJ, Kent CR, Magnuson KS, Martin WH, Rizzuti BJ, Sawyer PS, Perry BD, Brissette WH, McCurdy SP, Kudlacz EM, Conklyn MJ, Elliot EA, Koslov ER, Fisher MB, Strelevitz TJ, Yoon K, Whipple DA, Sun J, Munchhof MJ, Doty JL, Casavant JM, Blumenkopf TA, Hines M, Brown MF, Lillie BM, Subramanyam C, Shang-Poa C, Milici AJ, Beckius GE, Moyer JD, Su C, Woodworth TG, Gaweco AS, Beals CR, Littman BH, Fisher DA, Smith JF, Zagouras P, Magna HA, Saltarelli MJ, Johnson KS, Nelms LF, Des Etages SG, Hayes LS, Kawabata TT, Finco-Kent D, Baker DL, Larson M, Si M-S, Paniagua R, Higgins J, Holm B, Reitz B, Zhou YJ, Morris RE, O'Shea JJ, Borie DC. Prevention of organ allograft rejection by a specific Janus kinase 3 inhibitor. Science. 2003; 302:875-878. [PubMed: 14593182] 
87. Blumenkopf, TA.; Flanagan, ME.; Munchhof, MJ. Patent. EP 1235830. 2004. Japanese Patent. JP 2003516405. 2003. U.S. Patent. US 2001053782. 2001. U.S. Patent. US6627754. 2003. Patent. WO 0142246. 2001.

88. Ruggeri, SG.; Hawkins, JM.; Makowski, TM.; Rutherford, JL.; Urban, FJ. Japanese Patent. JP 2007039455. 2007. Patent. WO 2007012953. 2007.

89. Flanagan, ME.; Li, ZJ. Japanese Patent. JP 2005511696. 2005. U.S. Patent. US 2003130292. 2003. Patent. WO 03048162. 2003.

90. Cai W, Colony JL, Frost H, Hudspeth JP, Kendall PM, Krishnan AM, Makowski T, Mazur DJ, Phillips J, Ripin DHB, Ruggeri SG, Stearns JF, White TD. Investigation of practical routes for the kilogram-scale production of cis-3-methylamino-4-methylpiperidines. Org. Process Res. Dev. 2005; 9:51-56.

91. Sorbera LA, Serradell N, Bols J, Rosa E, Bozzo J. CP-690,550. Drugs Future. 2005; 32:674-680.

92. Jiang JK, Ghoreschi K, Deflorian F, Chen Z, Perreira M, Pesu M, Smith J, Nguyen DT, Liu EH, Leister W, Costanzi S, O'Shea JJ, Thomas CJ. Examining the chirality, conformation and selective kinase inhibition of 3-((3R,4R)-4-methyl-3-(methyl(7H-pyrrolo[2,3-d]pyrimidin-4-yl)aminopiperidin-1-yl)-3-oxopropanenitrile (CP-690,550). J. Med. Chem. 2008; 51:8012-8018. [PubMed: 19053756]

93. Changelian, PS.; Zwillich, SH. Patent. WO 2008029237. 2008.

94. Williams NK, Bamert RS, Patel O, Wang C, Walden PM, Wilks AF, Fantino E, Rossjohn J, Lucet IS. Dissecting specificity in the Janus kinases: The structure of JAK-specific inhibitors complexed to the JAK1 and JAK2 protein tyrosine kinase domains. J. Mol. Bol. 2009; 387:219-232.

95. Thoenen H, Barde YA. Physiology of nerve growth factor. Physiol. Rev. 1980; 60:1284-1335. [PubMed: 6159658]

96. DiStefano PS. Pharmacology of neurotrophic factors in models of neurodegenerative diseases. Annu. Rep. Med. Chem. 1993; 28:11-17.

97. Lad SP, Neet KE, Mufson EJ. Nerve growth factor: structure, function and therapeutic implications for Alzheimer's disease. Current Drug Targets- CNS and Neurological Disorders. 2003; 2:315334. [PubMed: 14529363]

98. Pattarawarapan M, Burgess K. Molecular basis of neurotrophin-receptor interactions. J. Med. Chem. 2003; 46:5277-5291. [PubMed: 14640536]

99. Nakagawara A. Trk Receptor tyrosine kinases: a bridge between cancer and neural development. Cancer Lett. 2001; 169:107-114. [PubMed: 11431098]

100. Rubin JB, Segal RA. Growth, survival and migration: the Trk to cancer. Cancer Treat. Res. 2003; 115:1-18. [PubMed: 12613191]

101. Bardelli A, Parsons DW, Silliman N, Ptak J, Szabo S, Saha S, Markowitz S, Willson JK, Parmigiani G, Kinzler KW, Vogelstein B, Velculescu VE. Mutational analysis of the tyrosine kinome in colorectal cancers. Science. 2003; 300:949. [PubMed: 12738854]

102. Weeraratna AT, Arnold JT, George DJ, DeMarzo A, Isaacs JT. Rational basis for Trk inhibition therapy for prostate cancer. The Prostate. 2000; 45:140-148. [PubMed: 11027413]

103. Zhang Y, Dang C, Ma Q, Shimahara Y. Expression of nerve growth factor receptors and their prognostic value in human pancreatic cancer. Oncol. Rep. 2005; 14:161-171. [PubMed: 15944784]

104. Lippa B, Morris J, Corbett M, Kwan TA, Noe MC, Snow SL, Gant TG, Mangiaracina M, Coffey HA, Foster B, Knauth EA, Wessel MD. Discovery of novel isothiazole inhibitors of the TrkA kinase: structure-activity relationship, computer modeling, optimization, and identification of highly potent antagonists. Bioorg. Med. Chem. Lett. 2006; 16:3444-3448. [PubMed: 16632359]

105. Wang T, Lamb ML, Scott DA, Wang H, Block MH, Lyne PD, Lee JW, Davies AM, Zhang HJ, Zhu Y, Gu F, Han Y, Wang B, Mohr PJ, Kaus RJ, Josey JA, Hoffmann E, Thress K, Macintyre T, Wang H, Omer CA, Yu D. Identification of 4-aminopyrazolylpyrimidines as potent inhibitors of Trk kinases. J. Med. Chem. 2008; 51:4672-4684. [PubMed: 18646745]

106. Thress K, MacIntyre T, Wang H, Whitston D, Liu Z-Y, Hoffmann E, Wang T, Brown JL, Webster K, Omer C, Zage PE, Zeng L, Zweidler-McKay PA. Identification and preclinical characterization of AZ-23, a novel, selective, and orally bioavailable inhibitor of the Trk kinase pathway. Mol. Cancer Ther. 2009; 8:1818-1827. [PubMed: 19509272]

Curr Top Med Chem. Author manuscript; available in PMC 2011 November 18. 


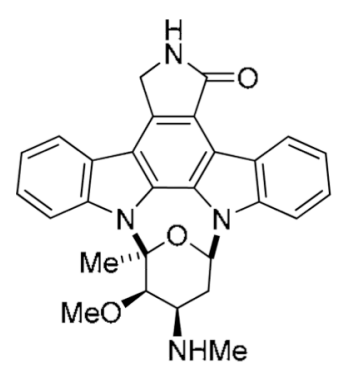

staurosporine
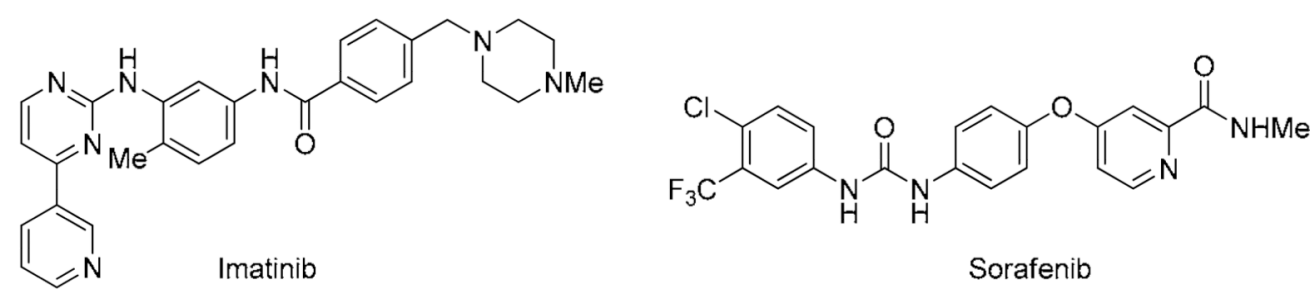

Figure 1.

Chemical structures of the well studied kinase inhibitors staurosporine, imatinib and sorafenib. 
<smiles>CNC(=O)c1ccc(C)c(-n2c(C)cc(OCc3ccc(F)cc3F)c(Br)c2=O)c1</smiles>

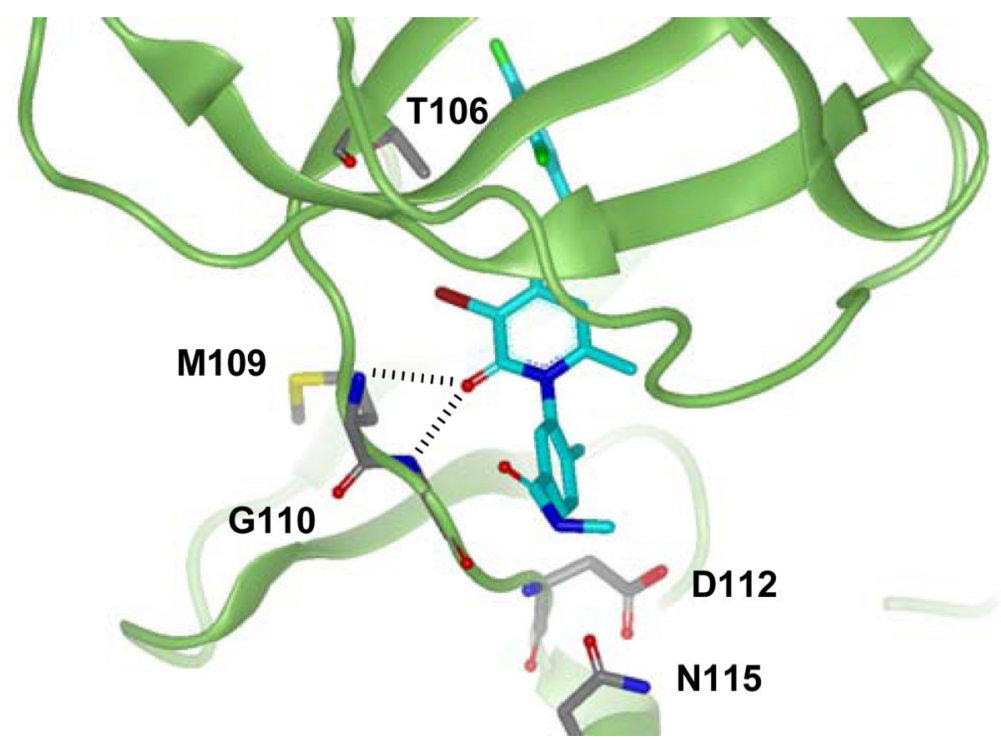

Figure 2.

Chemical structures of PH-797804 and a reproduction of the X-ray structure of PH-797804 bound to $\mathrm{p} 38 \alpha$ (PDB:3HLL). 
<smiles>CC(N)COc1cnc(Cl)c(/C=C/c2ccncc2)c1</smiles>

1<smiles>Cc1n[nH]c2ccc(-c3cncc(OC[C@H](N)Cc4c[nH]c5ccccc45)c3)cc12</smiles>

A-443654

AKT IC $50=0.16 \mathrm{nM}$

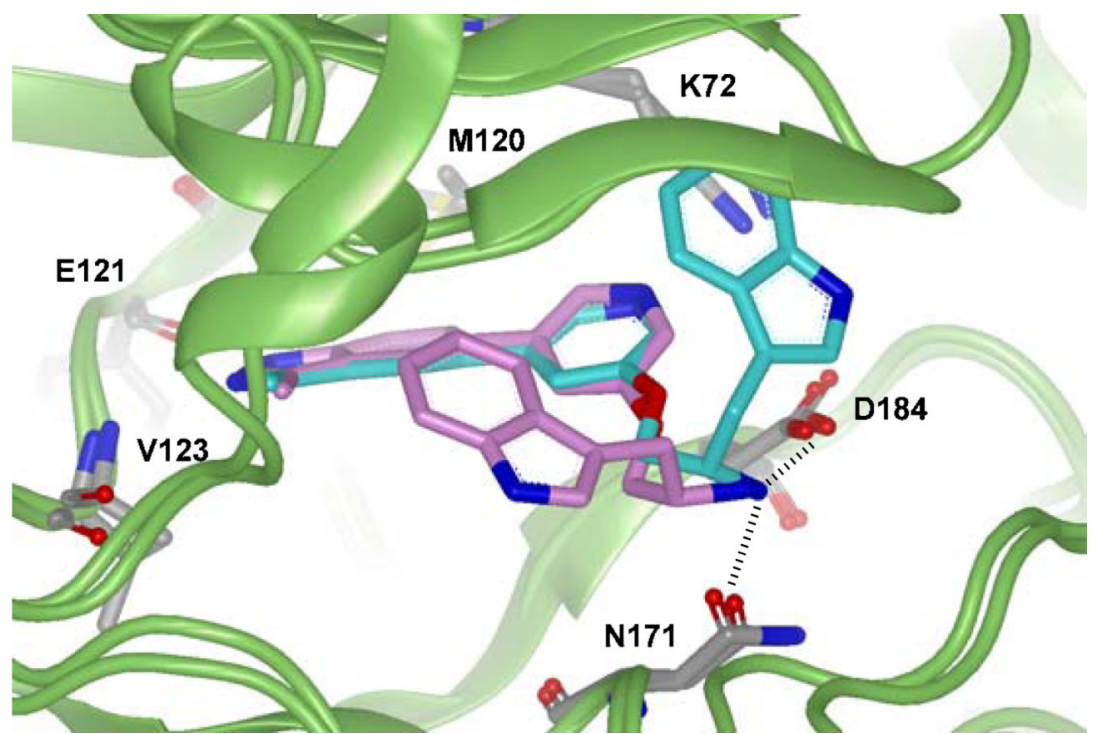

Figure 3.

Chemical structures showing the progression of chloropyridine 1 to A-443654 and reproductions and overlay of the X-ray structures of $\mathbf{A - 4 4 3 6 5 4}$ bound to PKA (PDB:2JDS) (cyan colored structure) and AKT2 (PDB:2JDR)(purple colored structure). Note; residue numbering reflects PKA structure. 
<smiles>CNc1nccc(-c2ccc(C(=O)NCCc3ccc(F)cc3)s2)n1</smiles>

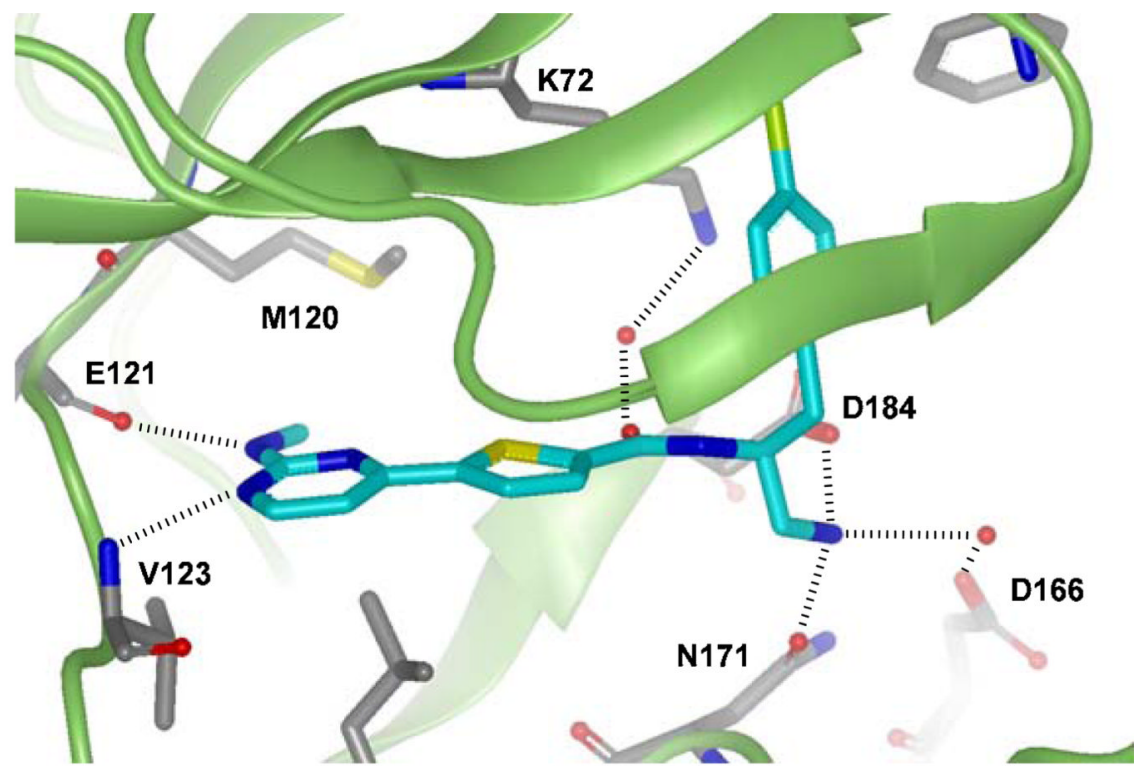

$\mathrm{AKT} \mathrm{IC}_{50}=2.6 \mathrm{nM} \quad \mathrm{Cl}$

Figure 4.

Chemical structures showing the progression of a lead AKT inhibitor $\mathbf{2}$ and the optimized $\mathbf{3}$ and a reproduction of the X-ray structure of $\mathbf{3}$ bound to PKA (PDB:2GU8). 
<smiles>COc1cc(/C=C/C[C@H](O)[C@H](O)C(=O)/C=C\C[C@@H](C)OC(=O)c2c(O)cc(OC)cc2O)cc(OC)c1</smiles>

FR148083

MEK IC ${ }_{50}=4 \mathrm{nM}$

ERK2 IC ${ }_{50}=80 \mathrm{nM}$

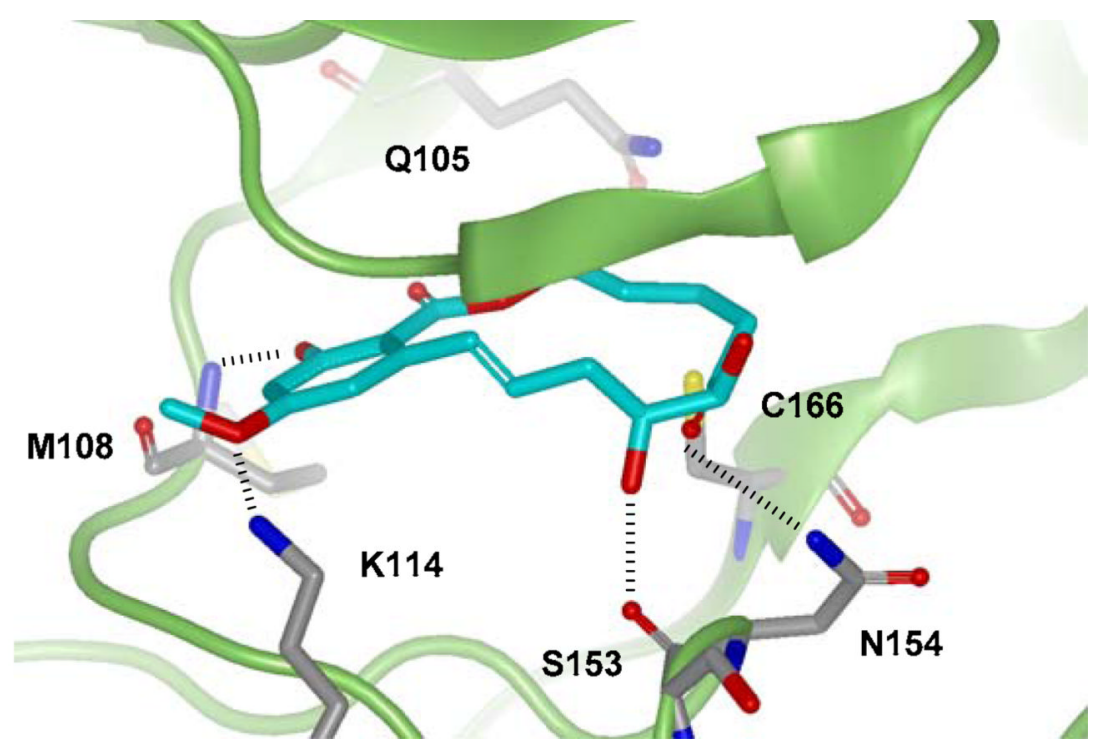

Figure 5.

Chemical structure of FR148083 and a reproduction of the X-ray structure of FR148083 bound to ERK2 (PDB:2E14). 
<smiles>CN(C)C(=O)c1cc(-c2n[nH]cc2-c2ccccc2)c[nH]1</smiles><smiles>c1ccccc1</smiles>

4

ERK2 $K \mathrm{i}=2.3 \mu \mathrm{M}$

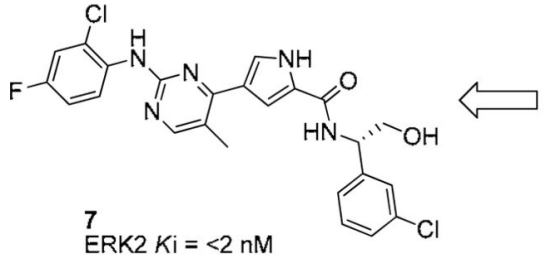

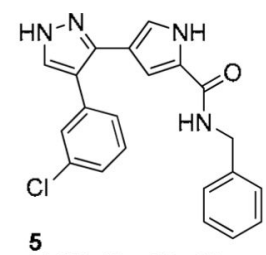

ERK2 $K \mathrm{i}=86 \mathrm{nM}$

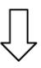

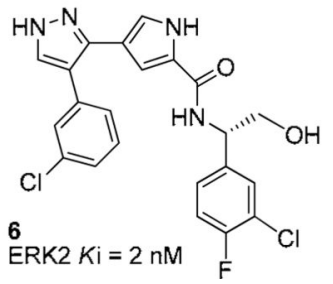

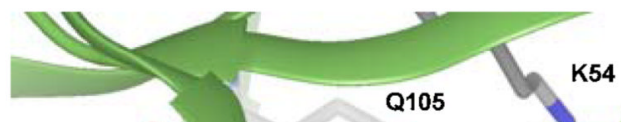
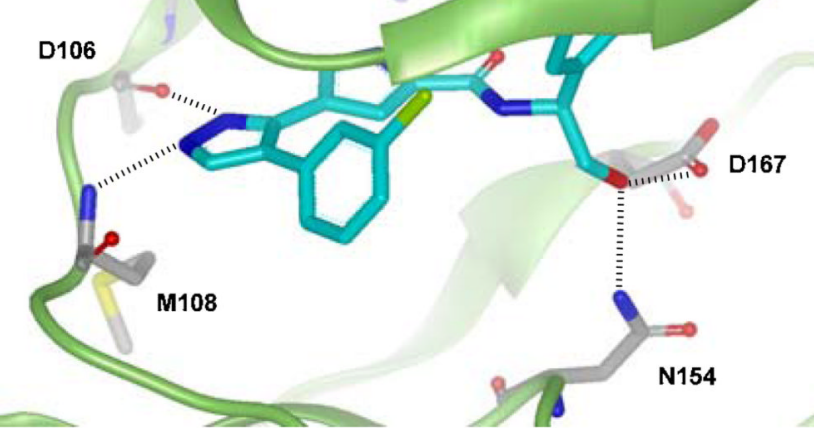

Figure 6.

Chemical structures showing the progression of a lead ERK2 inhibitor 4 to 7 and a reproduction of the X-ray structure of 6 bound to ERK2 (PDB:2OJJ). 
<smiles>[R]C1CCN(C(=O)CC#N)C[C@H]1N(C)c1ncnc2[nH]ccc12</smiles>

CP-690,550

JAK1 $\mathrm{Kd}=1.7 \mathrm{nM}$

JAK2 $\mathrm{Kd}=1.8 \mathrm{nM}$

JAK3 $\mathrm{Kd}=0.8 \mathrm{nM}$

TYK2 Kd $=260 \mathrm{nM}$<smiles>CN(C)c1ncnc2[nH]ccc12</smiles>

JAK1 $K d=N A$

$J A K 2 \mathrm{Kd}=270 \mathrm{nM}$

JAK3 $K d=180 \mathrm{nM}$

TYK2 Kd = NA<smiles>C[C@@H]1CCN(C(=O)CC#N)C[C@@H]1N(C)c1ncnc2[nH]ccc12</smiles>

8

JAK1 $K d=N A$

$J A K 2 \mathrm{Kd}=600 \mathrm{nM}$

JAK3 Kd $=190 \mathrm{nM}$

TYK2 Kd = NA<smiles>[R]C1CCN(C(=O)CC#N)CC1N(C)c1ncnc2[nH]ccc12</smiles>

10

JAK1 $K d=N A$

$J A K 2 \mathrm{Kd}=420 \mathrm{nM}$

JAK3 $\mathrm{Kd}=150 \mathrm{nM}$

TYK2 Kd $=$ NA

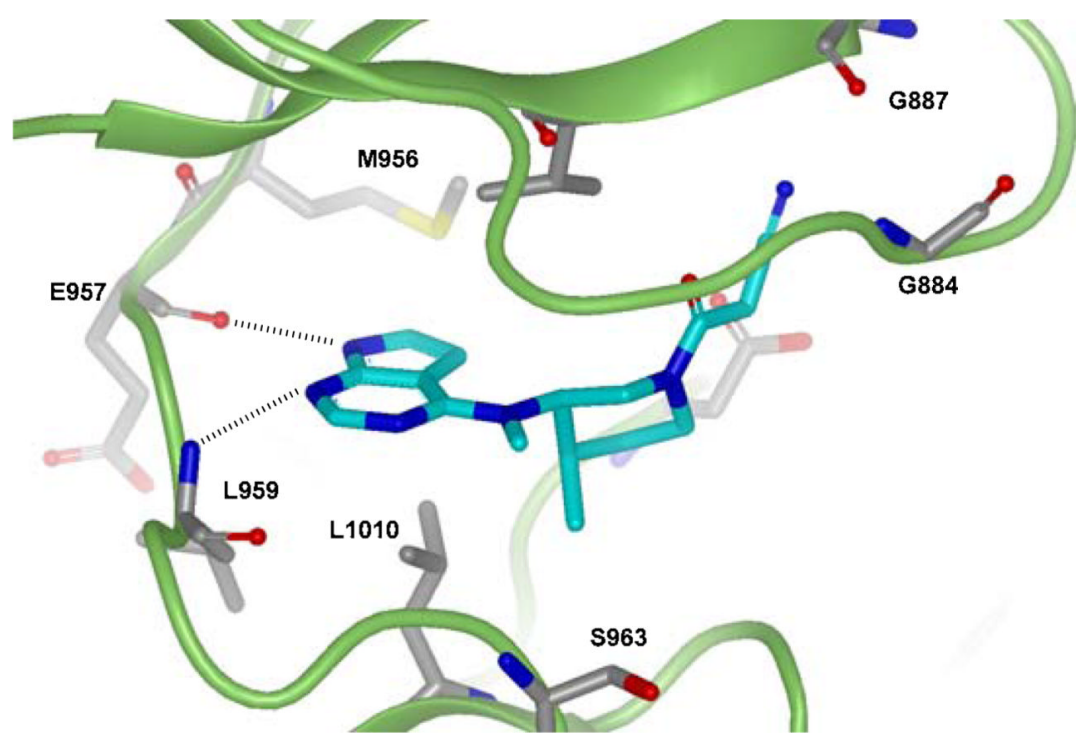

Figure 7.

Chemical structure of CP-690,550 and a reproduction of the X-ray structure of CP-690,550 bound to JAK1 (PDB:3EYG). 
Jiang et al.

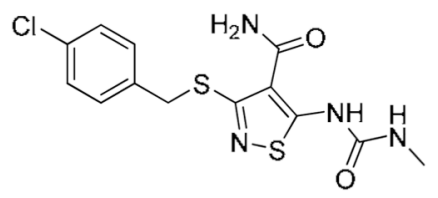

11

TrkA IC ${ }_{50}=7 \mathrm{nM}$

TrkA cell inhibition $\mathrm{IC}_{50}=300 \mathrm{nM}$

4-fold selectivity over VEGFR-2

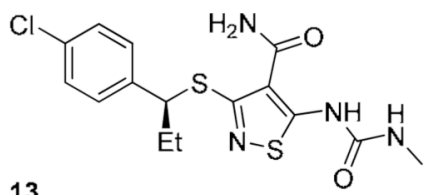

13

TrkA IC $50=52 \mathrm{nM}$

TrkA cell inhibition $\mathrm{IC}_{50}=978 \mathrm{nM}$

10-fold selectivity over VEGFR-2

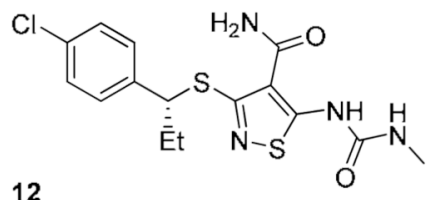

TrkA IC ${ }_{50}=4 \mathrm{nM}$

TrkA cell inhibition $\mathrm{IC}_{50}=46 \mathrm{nM}$

1300-fold selectivity over VEGFR-2
Page 21<smiles>NC(=O)Nc1snc(SC2CCCCc3ccccc32)c1C(N)=O</smiles>

15

TrkA IC ${ }_{50}=91 \mathrm{nM}$

TrkA cell inhibition $I C_{50}=>1 \mu \mathrm{M}$

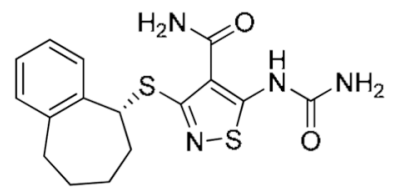

14

TrkA IC $\mathrm{IC}_{50}=<1 \mathrm{nM}$

TrkA cell inhibition $I_{50}=7 \mathrm{nM}$

Figure 8.

Chemical structures showing the progression of the lead TrkA inhibitor $\mathbf{1 1}$ to $\mathbf{1 4}$. 


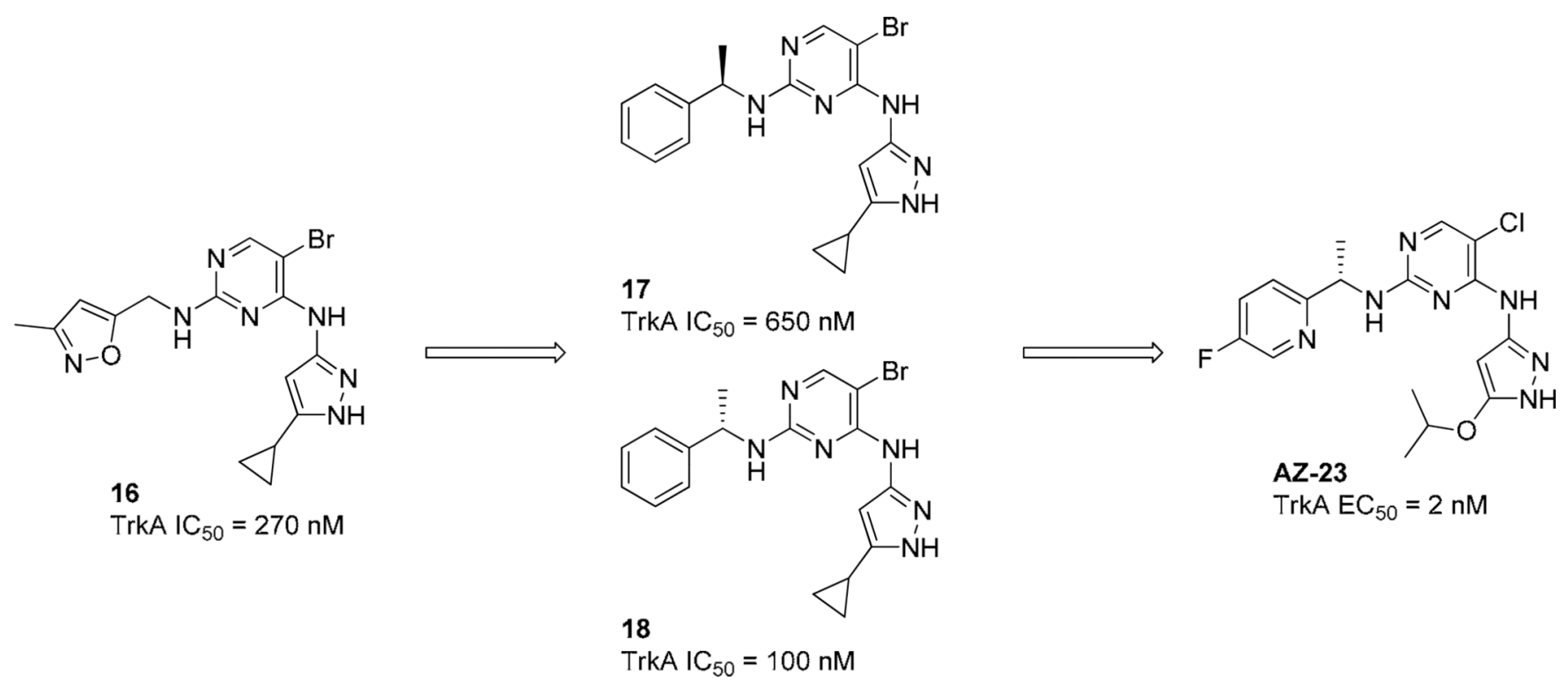

Figure 9.

Chemical structures showing the progression of the lead TrkA inhibitor 16 to AZ-23. 